\section{Pacific Northwest}

National Laboratory

Operated by Battelle for the

U.S. Department of Energy

\title{
RCRA Groundwater Quality Assessment Report for Single-Shell Tank Waste Management Area T (January 1998 through December 2001)
}
D. G. Horton
F.N. Hodges
V.G. Johnson
C.J. Chow

July 2002

Prepared for the U.S. Department of Energy under Contract DE-AC06-76RL01830 


\title{
DISCLAIMER
}

This report was prepared as an account of work sponsored by an agency of the United States Government. Reference herein to any specific commercial product, process, or service by trade name, trademark, manufacturer, or otherwise does not necessarily constitute or imply its endorsement, recommendation, or favoring by the United States Government or any agency thereof, or Battelle Memorial Institute.

\section{PACIFIC NORTHWEST NATIONAL LABORATORY \\ operated by \\ BATTELLE \\ for the \\ UNITED STATES DEPARTMENT OF ENERGY \\ under Contract DE-AC06-76RL01830}

Printed in the United States of America

Available to DOE and DOE contractors from the

Office of Scientific and Technical Information, P.O. Box 62, Oak Ridge, TN 37831;

prices available from $(615) 576-8401$.

\begin{abstract}
Available to the public from the National Technical Information Service, U.S. Department of Commerce, 5285 Port Royal Rd., Springfield, VA 22161
\end{abstract}

This document was printed on recycled paper. 


\title{
RCRA Groundwater Quality Assessment Report for Single-Shell Tank Waste Management Area T (January 1998 through December 2001)
}

\author{
D. G. Horton \\ F. N. Hodges \\ V. G. Johnson \\ C. J. Chou
}

July 2002

Prepared for

the U.S. Department of Energy

under Contract DE-AC06-76RL01830

Pacific Northwest National Laboratory

Richland, Washington 99352 


\section{Summary}

Single-shell Tank Waste Management Area (WMA) T at the Hanford Site is located in the northern 200 West Area. WMA T contains twelve primary single-shell carbon steel tanks, four ancillary tanks, and their auxiliary equipment. The tank farm was constructed in 1943 and 1944. During operations, tanks received mixed waste from the processing of spent reactor fuel to recover plutonium as part of the Hanford Site's defense mission. The tank farm ceased operations in 1980 and is currently regulated as a Resource Conservation and Recovery Act (RCRA) Interim Status Facility.

WMA T was placed in RCRA Groundwater Quality Assessment in 1993 and has remained in that status because of indications that contaminants from within the waste management area are entering groundwater.

The water table is declining and groundwater flow directions have changed in the vicinity of WMA T since initiation of assessment monitoring in 1993. These changes are a result of the cessation of effluent discharge to ground in 1995. Seven new RCRA monitoring wells have been constructed since 1997 to meet the groundwater monitoring needs resulting from changing water levels and flow directions and to assess contamination in groundwater.

Evaluation of groundwater data indicates that no RCRA-regulated contaminants from WMA T have affected groundwater. However, the contaminant technetium-99, regulated by the Atomic Energy Act, forms a plume detected near the northeastern corner of WMA T. That plume has its origin from the WMA and is largely contained near the top of the aquifer. This zone appears to have relatively low permeability based on pumping data obtained during well development and hydrological testing. In about 1997, the groundwater flow direction began to change from toward the northeast to toward the east or slightly north of east and, since then, the existing plume has apparently been drifting in that direction. If the measured flow velocity of $0.029 \mathrm{~m} / \mathrm{d}$ is representative of the aquifer in the area, the plume would have moved approximately 42 meters east of well 299-W11-27 since 1998 when flow directions became stable. The high concentrations of technetium-99 seen in well 299-W11-27 in 1998 have not reached well 299W11-39, which is 23 meters east of well 299-W11-27. This suggests either a slower rate of movement for the technetium-99 plume in the area or the mass of the plume passed to the north of the well. If tank waste contaminants are restricted to a low permeability portion of the aquifer, the lateral extent of the contaminants may be relatively small due to slow contaminant movement. 


\section{Contents}

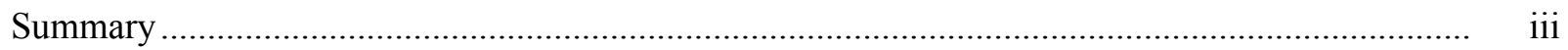

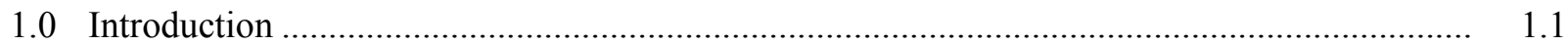

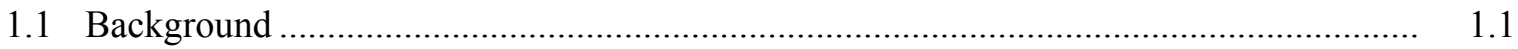

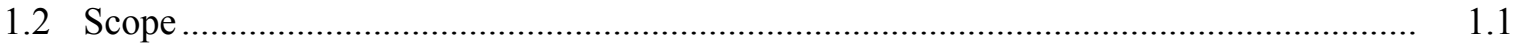

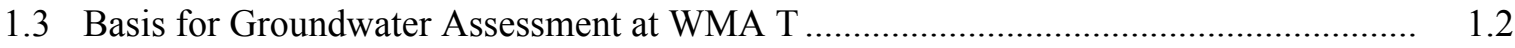

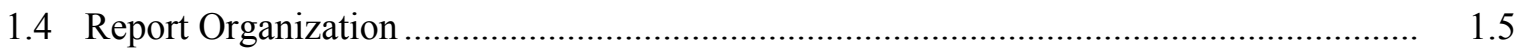

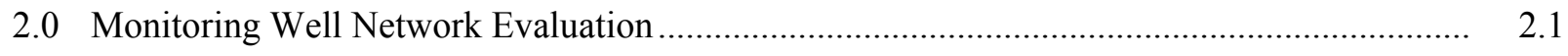

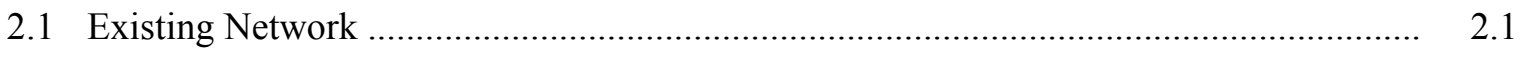

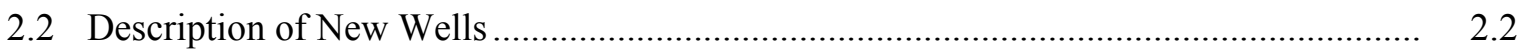

3.0 Rate and Direction of Groundwater Flow ............................................................... 3.1

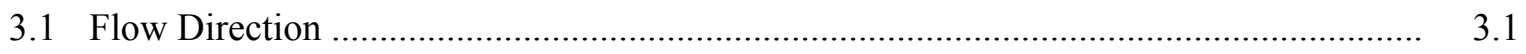

3.2 Borehole Tracer Dilution and Tracer Pumpback Testing........................................... 3.1

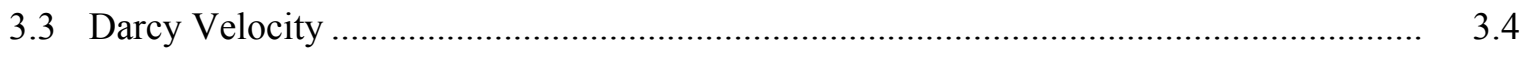

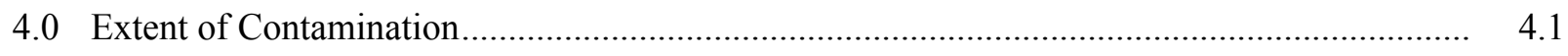

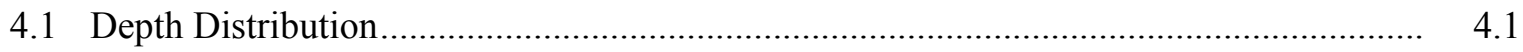

4.1.1 Conceptual Model Considerations ............................................................. 4.1

4.1.2 Vertical Distribution Data .......................................................................... 4.1

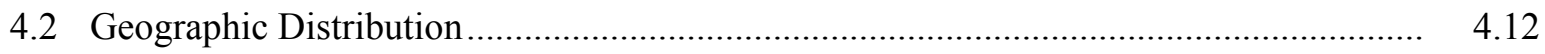

5.0 Maximum Contaminant Concentrations .................................................................. 5.1

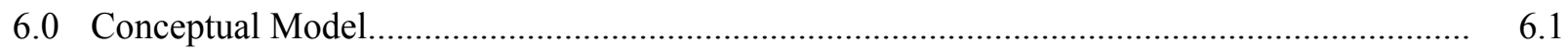

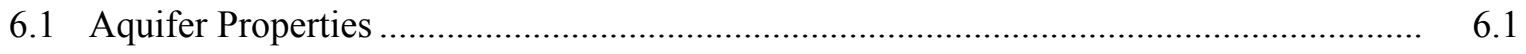

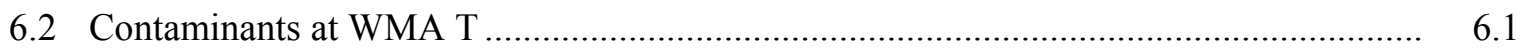


7.0 Conclusions

7.1 Rate and Extent of Contaminant Migration

7.2 Concentration of Contaminants

\section{Figures}

1.1 Location of Waste Management Area T on the Hanford Site ............................................. 1.2

1.2 Waste Management Area T, Surrounding Facilities, and Monitoring Well Locations. ............ 1.3

3.1 Water-Table Elevation Map for Waste Management Area T ............................................. 3.2

4.1 Depth Distribution of Key Contaminants, Well 299-W10-24, Waste Management Area T ..... 4.4

4.2 Technetium-99 Concentrations in Wells at Waste Management Area T .............................. 4.9

4.3 Nitrate Concentrations in Wells at Waste Management Area T.......................................... 4.11

4.4 Chromium Concentrations in Well Pair 299-W11-27 and 299-W10-24, Well Pair 299-W11-23 and 299-W11-39, and Well Pair 299-W11-28 and 299-W11-42

\section{Tables}

2.1 Construction and Lithologic Characteristics of the Screened Intervals of New Wells at Waste Management Area T

2.2 Development Pumping Data for Wells Drilled at Waste Management Area T Since 1997

3.1 Results from Tracer-Dilution and Tracer-Pumpback Tests at Well 299-W10-24 at Waste Management Area T

3.2 Tracer-Dilution Test Results for Well 299-W10-24 at Waste Management Area T

3.3 Hydraulic Properties from Slug and Constant Rate Pumping Tests and Calculated Darcy Velocities at Two New Wells at Waste Management Area T 
4.1 Discrete Depth Sampling Results from Well 299-W10-24 ........................................... 4.3

4.2 Technetium-99/Nitrate Ratios from Various Sources at Waste Management Area T.............. 4.5

4.3 Analytical Results for Groundwater Samples Taken During Drilling of Well 299-W11-42

4.4 Specific Conductance and pH for Samples from Well 299-W10-28 ................................. 4.7

4.5 Anions in Samples from Well 299-W10-28.....................................................................

5.1 Maximum Contaminant Concentrations for Groundwater Samples Collected from

Waste Management Area T Network Wells ..................................................................... 5.2 